\title{
The Speech Sounds of Arabic Language and their Effect on Learning English Pronunciation : A Contrastive Analysis
}

\author{
Dr. Samer Mahmoud Al-Zoubi \\ Assistant Professor \\ Ajloun National University \\ Jordan
}

\begin{abstract}
The main purpose of this qualitative and descriptive study is to investigate the effect of the Arabic language speech sounds on learning English language pronunciation. In this contrastive analysis, the researcher described the speech sounds system of the Arabic language in comparison with their counterparts of English. The researcher used the direct observation as an instrument to observe and register notes about the students' pronunciation of both languages. However, the results showed that there are speech sounds in the Arabic language that have counterparts in the English language and vice versa. Thus, these similarities between the speech sounds of the two languages facilitate and have positive effects on the process of learning the English language. The results also revealed that Arab EFL learners encounter many problems with learning English pronunciation especially with unfamiliar speech sounds that do not exist on their mother tongue since there are speech sounds in the Arabic language that do not have counterparts in the English language e.g. glottal stops. To sum up, due to these differences in the speech sounds of both languages, one can conclude that they have negative effects on the process of learning the English language and learners face difficulty in pronouncing these sounds correctly. Accordingly, mother tongue interference and overgeneralization rules affect the pronunciation and spelling of some English words. Finally, based on the results of this research, some suggestions and recommendations are presented which may help students and teachers in reducing Arab EFL learners' difficulties in improving their English pronunciation.
\end{abstract}

Keywords: Contrastive Analysis , Pronunciation , Speech Sounds , EFL

\section{Introduction}

Contrastive analysis is a second language acquisition approach that compares the features of the first language and second language to determine the similarities and differences between them. Yates (2002) defined pronunciation as the production of sounds that is used for making meaning that involves segmental, suprasegmental features, and voice quality. In fact, the Arabic language is the official language of education, science, technology and media in the Arab world, and the target language for the majority of L2 Arabic learners all over the world. In Arab countries, English is a foreign language which is a compulsory subject to be taught in all schools ranging from basic to secondary schools. However, English proficiency of secondary school graduates still creates dissatisfaction among teachers as well as parents. The unsatisfying quality of English pronunciation in Arab countries is related to different variables. (Qaid \& Ramamoorthy, 2011).

According to Kenworthy (1987), there were many factors that could affect the students' ability to speak English with correct pronunciation, such as the first language ( L1 ) interference, learner's attitude, learner's age, earlier pronunciation instruction, the inadequate language knowledge of English phonetics and phonology and the fact that they speak English just inside their classrooms but whenever they leave their classes, they use their own mother tongue. Consequently, when discussing the influence of L1 on L2, it is necessary to refer to Contrastive Analysis Hypothesis $(\mathrm{CAH})$ which states that those L2 elements that are similar to learner's L1 will be simple for him/her and those different elements will be difficult. In this context, it is an evident that the language teachers and language learners should know the structures of both L1 and L2. because such knowledge can help the language teacher identify the areas of influence of L1 on L2 and to develop some methods to resolve the interferences (Lado, R. 1957). 
For the purpose of this contrastive analysis between speech sounds of both Arabic and English languages, it is worthwhile to mention that the Arabic language has 28 consonant phonemes and 6 vowel phonemes $(8$ vowels in most modern dialects). All phonemes contrast between "emphatic" (uvularized) consonants and non-emphatic ones. Some of these phonemes have joined together in various modern dialects, while new phonemes have been introduced through borrowing or phonemic splits. A "phonemic quality of length" applies to consonants as well as vowels whereas Standard British English (also known as 'Received Pronunciation') has 24 consonant phonemes and 20 basic vowel phonemes (7 short vowels, 5 long vowels, and 8 diphthongs). while there are only five main vowel letters - a, e, i, o and u in received pronunciation, speakers use four times as many vowel sounds (Thelwall, Robin, 1990). Phonologically, English has about three times vowel sounds more than Arabic, so it is inevitable that some learners may fail to differentiate between some of the words they hear, such as pin / pen or bad / bed, and will have difficulties in saying such words appropriately (Marcel, 2012 ).

Amayreh (2003) stated that there were three levels of Arabic language: Firstly, Modern Standard Arabic which is used in religious ceremony and literature. Secondly, educated Spoken Arabic that is used in schools and public arenas. Thirdly, Colloquial Arabic which is used at home and in the community; significant dialectal variability exists among colloquial forms. Other facts about the Arabic language. First, the Arabic language has emphatic consonants, such as /t/,/d/, /ð/, and /s/. Emphatic consonants are described as those sounds that are produced with the root of the tongue retracted toward the pharyngeal wall. Second, in postvocalic environments the $/ \mathrm{r} /$ is trilled; however, in prevocalic environments, the $/ \mathrm{r} /$ is tapped. Thirdly, phonemes in the Arabic language that are not found in the English language include the following: $/ \mathrm{t} /, / \mathrm{d} /, / \mathrm{d} /, / \mathrm{s} /, / \chi /, / \mathrm{s} /, / \mathrm{h} /, / \mathrm{S} /$, and $/ \mathrm{P} /$. Next, phonemes in the English language that are not found in the Arabic language include the following: /p/, /v/, /x/, /3/, /g/, and /y/. Finally, dialectal variations in phonology are evident in the Arabic language. So, it is important to recognize this when assessing an Arabic language speaker (Amayreh, 2003).

Because this research concentrates on the speech sounds of the Arabic language and their effects on learning the English language pronunciation, there are two types of transfer happening during learnering L2.On one hand ,positive transfer that refers to the similarities found in both L1 and L2; that can be founnd in the grammatical structures, phonology, phonetics, and morphology . Thus, these similarities are believed to facilitate the process of learning L2. On the other hand, negative transfer refers to the differences in the grammatical structures, phonology, and morphology of the L2 compared to the L1. However, it is believed that negative transfer exists as an obstacle for learners in learning L2. In the context of Arab EFL learners learning the English language as a second language, both positive and negative transfer occur in the process of learning such as in grammatical structures, phonology, phonetics, and morphology. (Johansson, 2008).

Basically, the researcher's interest in studying the speech sounds of the Arabic language and their effect on learning the English language pronunciation is derived from the fact that it is worth studying as there is little research in this field. The process of teaching and learning pronunciation should be paid more attention by both teachers and learners whether English is learned as a foreign language or as a second language, (Ha, 2013). Many people around the world have a strong desire to learn and speak English with correct pronunciation since an English learner with a limited pronunciation performance may lose his/ her self-confidence in social interactions, which "negatively affects estimations of a speaker's credibility and abilities" (Gilakjani, 2012, p. 119). In other words, learners with good English pronunciation tend to be understood despite their grammatical mistakes in the speech. However, having a good knowledge of English grammar is not an insurance of intelligibility, meaning "how much of the speech is actually understood by interlocutors" (Munro, 2011, p.9).

Moreover, the phonemic inventory of Arabic consonants is represented by a wide range of sounds, among which are the universally less frequent uvular, pharyngeal and glottal places of articulation. As a result, it is noticed that Arabic speech sounds have considerable effects on EFL learners since it lacks some sounds which exist on English language, such as the sounds $/ \mathrm{p}, \mathrm{y}, \mathrm{d}, \mathrm{v}, 3 \ldots$ /and others. However, mother tongue interference and overgeneralization rules affect the pronunciation and spelling of some English words. For example, some Arab learners write the word" knife" as" nife " with deletion of the letters "k" and "e" since they are silent and mispronounce it as/ knaife/. Also, other learners pronounce the word tongue" as /t $\wedge \mathrm{y} \mathrm{u}: / \mathrm{instead}$ of $/ \mathrm{t} \wedge \mathrm{y} /$. Therefore, the researcher paid more attention to such negative effects on learning the English language pronunciation in this research.

\section{2 Purpose of the study}

This study aims at achieving the goals which could be stated as: 
1- Showing how the speech sounds of the Arabic language affect directly and indirectly on the level of grasping the English language pronunciation.

2- Showing the procedures through which the Arab EFL learners can get over such pronunciation difficulties.

3- Identifying the speech sounds of the Arabic language which don't have counterparts in the English language.

4- Identifying the practical procedures to improve the pronunciation of Arab EFL learners to speak English like native speakers.

\subsection{The Significance of the study}

The importance of this study lies in explaining the pronunciation difficulties that face Arab EFL learners in learning English due to some phonemes in English that are not found in Arabic include the following: $/ \mathrm{p} /, / \mathrm{v} /, / \mathrm{x} /$, $/ 3 /, / g /$, and $/ \mathrm{y} /$. As an English teacher and then as a professor and a researcher in teaching English, it is noticed that mother tongue interference affects the students' pronunciation of English words, the researcher ,however, tried to help the learners to overcome such difficulties through clarifying and showing them the differences and similarities between their L1 speech sounds and English counterparts.

\subsection{Statement of the Problem}

The researcher noticed that Arab EFL learners have many difficulties in pronouncing some English speech sounds that lead to differences in pronouncing them which could affect acquiring English language pronunciation appropriately. Therefore, he decided to show these difficulties and differences, examine them and provide the standard pronunciation for these speech sounds.

\subsection{Questions of the study.}

1- What is the speech sounds in the Arabic language that does not have counterparts in the English language and vice versa?

2- How does the mother tongue (Arabic Language) interfere in pronouncing some sounds in English?

3-What are the practical procedures to improve the English language pronunciation of Arab EFL learners?

\section{Literature Review}

\section{2 .1 Previous Studies}

Kharma \& Hajjaj (1989) conducted a study to identify problems that face Arab students of English language at initial stages; they presented four main areas of difficulty. As far as consonants are concerned, they presented two problematic issues. First, certain pairs are confused by learners such as $/ \mathrm{g} /$ and $/ \mathrm{J} /$ as in chair and share ; $/ \mathrm{v} /$ and $/ \mathrm{f} /$ as in fast and vast; $/ \mathrm{d} z /$ and $/ 3 /$ as in jar and erosion; $/ \mathrm{p} /$ and $/ \mathrm{b} /$ as in pin and bin; $/ \mathrm{y} /$ and $/ \mathrm{n} /$ as in $/ \mathrm{sin} /$ sing and $/ \mathrm{sing} / \mathrm{sing} ; / \mathrm{s} /$ and $/ \theta /$ as in sin and thin. Second, learners insert a short vowel to break up the long consonant clusters to pronounce them as in /siprin/ for spring; /wI IId/ for wished; /a:skid/ for asked. In vowels, two types of difficulty are identified. First, certain diphthongs are replaced by other sounds due to L1 interference for example,

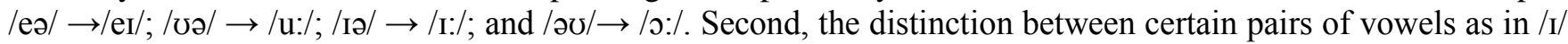
and /e/ as in sit and set; $/ \Lambda$ and /p/ as in luck and lock; /əv/ and /o:/ as in coat and caught (Kharma \& Hajjaj, 1989, p. 16).

In his study, O'Connor, J .p. (1967) specified the difficulties facing speakers of Arabic when pronouncing some English sounds, including both consonants and vowels. Regarding the consonants, the results showed that: / t / and / d / are dental stops in Arabic, while in English they are alveolar stops; sequences of three or more consonants do not occur in many forms of Arabic. Consequently, careful attention must be paid to these, especially in order to prevent the occurrence of a vowel to break up the consonant sequence. With reference to vowel speech sounds, the difficulties facing speakers of Arabic when pronouncing some English sounds. The results showed the followings : / I / and / e / are confused ,/ e / being used for both , / $\mathfrak{x} /$ and / b / are not entirely independent in Arabic and there is a danger of replacing one by the other in some places , / a / and / b / are confused, an intermediate vowel being used for both , / a: / is not always made long, and is then confused with / $/$ or / b / , / 3: / is replaced by a vowel of the / / or / e / type followed by Arabic / $\mathrm{r} /$, / ei / is replaced by the usually non-diphthongal vowel in Arabic / beit / " house ", / əv / is replaced by the non-diphthongal vowel in Arabic / m:z / banana and /iə, eə, və / are replaced by the nearest vowel sound, / i: , ei , u: / +Arabic / r /.

Oxford (1990) developed a taxonomy for Pronunciation Learning Strategies (PLS) aiming at helping learners improve suitable pronunciation of L2. This taxonomy was classified into two groups: the direct and indirect strategies. 
The direct strategies include memory strategies (Representing sounds in memory such as remembering words by making auditory rather than visual representations of sounds), cognitive strategies (including actions that are directly involved in studying and practicing the target language pronunciation such as repeating after the teacher), and compensation strategies (helping facial muscles to become accustomed to moving in new ways to acquire the target language pronunciation by producing approximate sounds). On the other hand, the indirect strategies, include the affective strategies (evaluating one's own pronunciation by praising oneself for correct pronunciation), metacognitive strategies (searching for practice and trying new sounds), and social strategies (practicing with others and correcting others' pronunciation mistakes). For Oxford (1990), the two most frequently utilized strategies are cognitive from the direct group and the metacognitive strategies pertaining to the indirect category.

Avery and Ehrlich (1992) pointed out that learners transfer their L1 sound patterns into the second language and this transfer is likely to cause foreign accents. It is reflected by the mispronunciations of words by non-native speakers. In this respect, Avery and Ehrlich claimed that the sound system of the L1 can influence the learners' pronunciation of L2 in at least three ways. First, when there is a sound in the L2 which is absent from the learners' native sound inventory or vice versa, learners may not be able to produce or even perceive the sound(s). Second, when the rules of combining sounds into words (i.e., phonetic constraints/rules) are different in the learners' L1 from those of the L2, they cause problems for learners because these rules are language specific as they can be different from one language to another. Thirdly, since the rhythm and melody of a language determine its patterns of stress and intonation, learners may transfer these patterns into L2.

Barros (2003) identified and analyzed the difficulties encountered by Arabic speakers when pronouncing English consonants to see the influence of learners' L1 on the acquisition of the L2 pronunciation. The participants were a group of Arabic speakers coming from different Arab countries with different dialect Arabic backgrounds. All participants were in contact with the L2 group and culture after the age of puberty for at least four years. The results showed that eight English consonants, namely, /y/, /p/, /v/, /d/, /1/, /dz/, /3 /, and $/ \mathrm{r} /$ are identified as problematic ones for Arabic speakers. He also found that interference of L1 seems to be the major reason contributing to pronunciation problems that might differ from one Arabic speaker to another, depending on the dialect variety of Arabic they use.

Khattab et al. (2006) examined the production of the phonemic contrast between the plain coronal stop /t/ and its emphatic counterpart /t $\mathrm{f} /$ in Jordanian Arabic in the environment of the high vowel /i/ and the low vowel /æ/. They reported F1 raising and F2 lowering at the onset of the emphatic vowels (no other vowel positions were measured) relative to their corresponding values in the plain vowels for both high and low vowels. Furthermore, Voice Onset Time (VOT) that is an important feature to distinguish between voiced and voiceless stops in various languages. Thus, they found that the VOT of emphatic consonants was significantly shorter than the VOT of plain consonants.

Marcel (2012) identified three problems Arab students have in learning English pronunciation. First, Arab EFL learners have difficulty distinguishing between /p/and /b/. Since Arabic has no /p/ sound Arab speakers will often say /p/ as /b/: like banda, bear, and bolice. Second, they have difficulty in knowing the difference between /f / and /v/ because there is no /v/ in Arabic. So you will hear many Arab EFL learners say 'fery' instead of 'very'. This is not as widespread at the /p/ vs. / b / sound. Third, English has many vowel sounds while Arabic only has a few vowel sounds. The words 'pit', 'pet', 'put', 'pot', and 'pat' might be the hardest in the entire language for Arabic speakers to pronounce and recognize. Words that are only differentiated by their vowel sound are tough. Some Arabic students do not know the difference in sound between 'bomb', 'pump', and 'bump'. The /o/ and / $\Lambda /$ sounds are hard for them as well as the /p/ and /b/. Another example is the difference between 'sit' and 'set' which causes problems to Arabic students. The /e/ sound in 'set' just is not found in Arabic. Many Arabs will say 'sit' instead of 'set'. However, these mistakes do not cause too much difficulty in understanding. As long as the word that is said incorrectly is in a sentence to give it context an Arabic student can understand it.

Alshangiti, W (2015) conducted a study entitled Speech production and perception in adult Arabic learners of English: A comparative study of the role of production and perception training in the acquisition of British English vowels. The results of this study demonstrated that Arabic speakers found English vowels were more difficult than consonants, though there were some confusions between some consonant contrasts; $/ 3 /-/ \mathrm{d} 3 /, / \mathrm{J} /-/ \mathrm{t} /$, $/ \mathrm{m} /-/ \mathrm{n} /-/ \mathrm{y} /$. The confusions that Arabic speakers make can be explained with reference to the relationship between the phonemic inventory in their L1 compared to that of the L2. Specifically, they find the phonemes that do not occur in their L1 harder to perceive and produce than those that do occur in their L1. 
The researcher assumed that given Arabic consonant numbers (28), and the number of vowels (6), they would find vowels more challenging than the consonants. The findings of this study supported the hypothesis that Arabic participants found vowels more challenging than consonants.

\section{2 . 2 An overview of the concepts of speech sounds in both Arabic and English}

\subsection{1 - The Consonants System of Classical Arabic}

For contrastive analysis purposes, the consonant inventories of Arabic and English languages are both outlined. The phonemic inventory of the Arabic language consonants is represented by a wide range of sounds, among which are the universally less frequent uvular, pharyngeal and glottal places of articulation. There are 28 consonant phonemes in the Arabic language as shown below. Nevertheless, consonants have their own system to be produced. They depend on the parameters of sounds: Voicing, place of articulation and manner of articulation. Therefore, the sound /b/ is described as a voiced bilabial stop. This is an oversimplified and an easy way to understand things and set a starting point. (Spencer, 1996. p 11-13). Basically, it is essential to describe the speech sounds of the Arabic language to illustrate clearly their effects on EFL learners. It is better to describe them as follows:

\section{Stops}

Arabic language has eight plosive consonants / ,b, t, d, q, ?/ being unique as all as Classical Arabic in having "...five different places of articulation." (O'Connor, J.D. 1983 p.224). This will not include the so called emphatic consonants because of their velarization. On the other hand, English has three different places of articulation in the domain of stops, namely, /p/, /t/, and /k/.

\begin{tabular}{|c|c|c|}
\hline Phoneme & Allophone & Description ,occurrence and example \\
\hline$/ \mathbf{p} /$ & {$[\mathrm{b}]$} & $\begin{array}{l}\text { Voiced bilabial stop . It occurs in all positions . } \\
\text { "baba" dad }\end{array}$ \\
\hline$/ \mathrm{t} /$ & {$\left[\mathbf{t}^{\mathrm{h}}\right]$} & $\begin{array}{l}\text { Voiceless unaspirated (dental)stop. It occurs in all positions in complementary } \\
\text { distribution with }[\mathrm{t}] \text { the latter appearing only in the beginning of stressed } \\
\text { syllables and released in word- final positions voiceless aspirated (dental)stop. } \\
\text { [tu:t] "blackberries" }\end{array}$ \\
\hline$/ \mathrm{d} /$ & [d] & 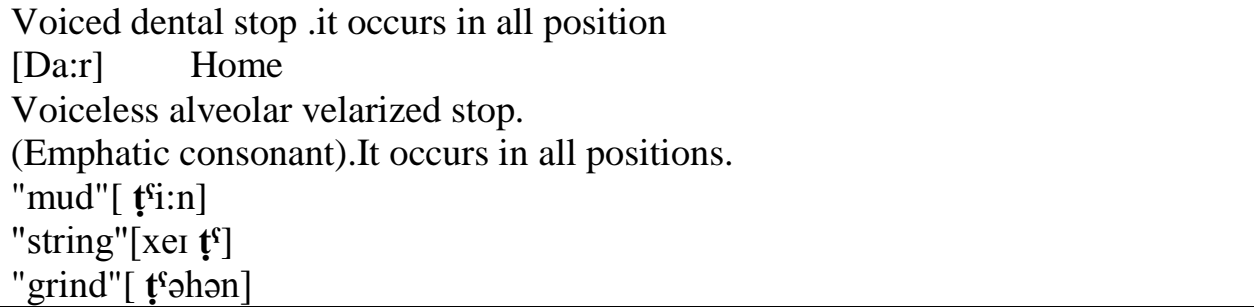 \\
\hline$/ \mathrm{d} / /$ & {$\left[d^{\mathrm{S}}\right]$} & $\begin{array}{l}\text { Voiced alveolar velarized stop . It occur in all positions . } \\
\text { [d'ajf] "guest" } \\
\text { [re d`?]"satisfaction" }\end{array}$ \\
\hline \multirow[t]{2}{*}{$/ \mathbf{k} /$} & {$[\mathbf{k}]$} & $\begin{array}{l}\text { Voiceless unaspirated velar stop. it occurs in all positions in } \\
\text { complement the latter appearing only in the begin and released in word final } \\
\text { positions. } \\
\text { Book [bok] }\end{array}$ \\
\hline & {$\left[\mathrm{k}^{\mathrm{h}}\right]$} & $\begin{array}{l}\text { Voiceless aspirated velar stop. see[k] above. } \\
\text { [khtəba] "he wrote" }\end{array}$ \\
\hline$/ \mathbf{q} /$ & [q] & $\begin{array}{l}\text { Voiceless unaspirated uvular stop. It occurs in all positions. In some dialects, } \\
\text { the consonant phoneme/q/ will replaced by /g/ which ,as a result appears } \\
\text { initially, and finally } \\
\text { [ga:l] he said }\end{array}$ \\
\hline
\end{tabular}

\section{Fricatives}

The second set of consonants falls under the category "fricatives""the rough, turbulent flow that occurs in the air stream during a fricative is produced in two ways: in the case of [f] for example, it is the result of the air passing through a narrow gap , or it may be due to the air stream first becoming speeded up being forced through a narrow gap and then being directed over a sharp edge, such as the teeth as in the production of [s]. 
It is the presence of the two possible mechanisms that the number of different fricatives is larger than that of stops or nasals." (Ladefodged ,P. 1982 pp.152-153).

[f]

Voiceless labio-dental fricative .It occurs in all positions.

[O]

$$
\text { [Kæfi:] "enough" , [f3:g] "over" , [seif] "sword" }
$$

Voiceless dental fricative. It appears in all positions

[ð]

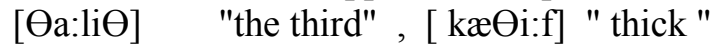

Voiced dental fricative .It occurs in all positions .

[ðanab] "tail", [kða:b] " make lie"

[S]

Voiceless alveolar fricative .It occurs in all positions

[sa:r] "walk" , [d3ris] "bell" , [midraesih] "school"

[Z]

Voiced alveolar fricative .It occurs in all positions.

$$
\text { [zəhrəh] "flower" , [lo:z] "almond" }
$$

\section{['s]}

Voiceless velarized alveolar fricative . It occurs in all positions

[ð`]
[ja's u:m] "fast"
['sawt] "sound" ,

Voiced velarized (interdental) fricative . It occurs in all positions.

[]]

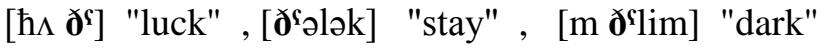

Voiceless palate -alveolar fricative . It occurs in all positions .

[Jərıbə] "drank", [ri:f] "feathers" , [IJrəb] "Drink"

[d]

Voiced palate -alveolar (affricate). It occurs in all positions

[X] [dz:ml] "camel" , [rədzə] "shake" , [fə dz r] "dawn"

Voiceless velar fricative. It appears in all positions.

[8] [Xっ:x] "plums" , [fəxr] "pride"

Voiced velar fricative. It occurs in all positions.

[h] [y ədən] "tomorrow" , [fa:re y] "empty" , [ja y rəg] "sink"

Voiceless pharyngeal fricative. It occurs in all positions.

[C] [ra:h] "he went" , [ha:r] "hot" , [jəhlog] "he shaves"

Voiced pharyngeal fricative .It occurs in all positions.

[h] [Gru:s] "bride" , [mSbəd] "temple" , [dəfৎə] "pushing"

Voiceless glottal fricative. It appears in all positions.

\section{- Nasals}

[ha:t] "bring" , [ta:h] "went astray" , [elha:m] "inspiration"

[m]

Voiced bilabial nasal stop. It occurs in all positions.

[mi:n] "who" , [əmi:r] "prince, [sa:m] "poisonous"

[n]

Voiced alveolar nasal . It occurs in all positions.

[na:m] "sleep" , [benet] "girl" , [ ba:n] " appear". 
"Nasals are sounds produced while the soft palate is lowered to allow an audible escape of air through the nose." (Crystal, D. 1983 p.237)

\section{- Laterals}

"Sounds where the air escapes around ONE or BOTH sides of closure made in the mouth." (Crystal ,D. 1983 p.205).

[1]

Voiced alveolar lateral. It occurs in all positions. [la:sS] " sting" , [meleh] "salt", [ga:1] "said " .Notice that the velarization of / 1/often has effect of a retracting and lowering slightly the articulation of a proceeding front vowel.

\section{- Glide}

Crystal, D. (1983) identifies flap as , "Any sound produced by a single rapid contact between two organs of articulation excluding vocal cords vibration."

$[\mathrm{r}]$

Voiced alveolar glide. It appears in all positions.

/'R'/

[rowa] "he irrigated" , [ dpma:r] "destruction"

Voiced velarized glide. It occurs in all positions.

[sa:r] "pleased"

\section{- Semi-Vowels}

$/ \mathbf{w} /$

Voiced labio-velar glide (semi-vowel).It occurs in all positions.

[wein] "where", [wor] "threw"

To sum up, the following points give a brief summary of Classical Arabic.

$1-/ \mathrm{p} /$ is a phoneme that does not exist in Classical Arabic.

2 - In some dialects, there is a general tendency to replace $\left./{ }^{5}\right] /$ by $/{ }^{5} \mathrm{~s} /$, both being velarized for example in the word [ $\left.{ }^{\varsigma} æ r æ b\right]$ meaning "to hit " the /d/ will be replaced by //s $/$, thus the pronunciation, in fact, becomes easier.

3- /q /is also substituted by /g/, shifting form uvular to velar for example the word [qælæ]

meaning 'he said ' is actually pronounced as [gæl], the latter being a characteristic of the dialect.

4- The consonant phoneme / ð/ undergoes the replacement process. It is replaced by the counterpart / d₹/ . [hæðæ] $[$ hæ's æ] both meaning "this". Velarized

5- / v / Phoneme does not exist in Classical Arabic, and if it exists (only in borrowed names), it is replaced by /f /

.e. g [tælfizj:: n] "television" would be pronounced.

6- / $\mathrm{g} /$ phoneme do not occur in Classical Arabic.

\subsection{2 - The Vowel System of Classical Arabic}

It is of utmost significance saying that Classical Arabic retains the vowels, whether short or long .Generally speaking, there are variations that, in certain cases might be considered misleading. As previously mentioned, the vowel quality is determined by first, the position of the tongue in the Mid mouth, hence, the words front, central, back, high, mid and low; second, the lip rounding or unrounding relating to the shape of the lips throughout the production of vowel phonemes. However there are three short vowels in Arabic $/ \mathrm{i} /, / \mho /, / \mathfrak{x} /$ which contrast phonemically with their long counterparts, /i:/,/u:/and /a:/. (Al-Ani, S.1970) .Once again, there should be a distinction between vowels produced in isolation and in connected speech. Consequently, it is noticed that "almost all vowels, when reduced, are initiated with the glottal stop. Furthermore, it is observed that almost all vowels in isolation seem to have some sort of abrupt initiation (the amount of which varies from one vowel to another".

Another important characteristic is that the relative duration of the vowel is almost twice as long when in isolation as when they are in speech sequences. Besides, the long vowels seem to be twice the length of the short vowels in either setting, (ibid,p.22). Examples of Arabic vowels: [i] / min/ "from" , 'cough'—/goh/

[i:] [ti:n] " figs" , u: "fence"—/su:r/

/mæt/ "he died" "shade" —/fai//fəi/

[ba:b] "door" aw "or" — PawNote that the last two phonemes are diphthongs that bear some resemblance English diphthongs /ai/ and /a-u/. The consonants air ,"w" and "y" were used to indicate the long and /i/. "The signs are put above or below the consonant which precedes the vowel." (Tritton, A. 1974) 


\begin{tabular}{|l|c|l|l|}
\hline Name & Sign & Sound & Symbol \\
\hline Short & - & As in sin & I \\
\hline Long & & As in yeast & i: \\
& S & & \\
\hline Short & - & As in put & U \\
\hline Long & As in food & U \\
\hline Short & - & As in bat & $\mathscr{2}$ \\
\hline Long & - & As in man & a: \\
\hline
\end{tabular}

There are two Diphthongs:

As in south English "fight"

As in south English "shout' /

$9 \quad \mathrm{av}$

ai

Neat an emphatic consonant [a ]short is like the vowel in 'not' [a] long is like that in "was" (drawled); and [ay] becomes more like the sound in "boy "Under these circumstances, there is no English equivalent of [aw].

\subsection{3 - International Phonetic Alphabet (IPA) symbols for English speech sounds: Consonants}

The International Phonetic Alphabet (IPA) is a system where each symbol is associated with a particular English sound. By using IPA learners can know exactly how to pronounce a certain word in English. This helps in improving English pronunciation and feeling more confident speaking in English.

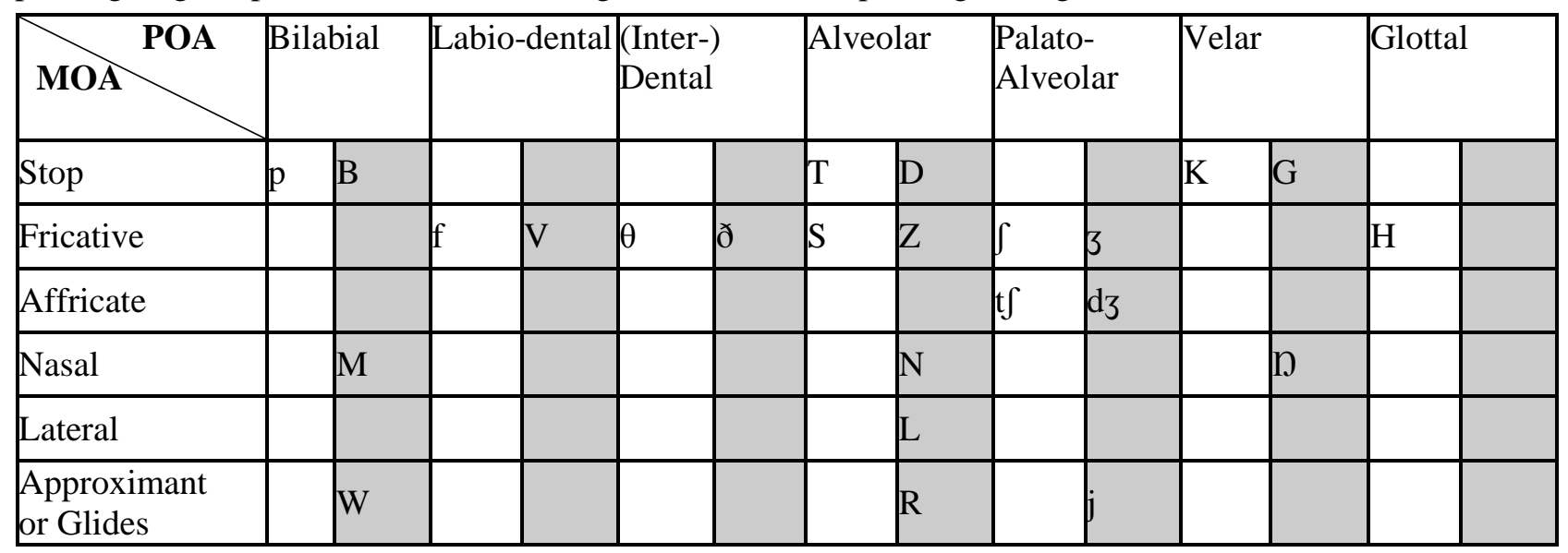

Shaded =voiced , Unshaded $=$ voiceless

The table above showed that the English language has twenty four consonants.As for the MOA there are six stops / b, p , t d , k , g /, two affricates / t $\int, \mathrm{d}_{3} /$, none fricatives / f, v, $\theta, \mathrm{d}, \mathrm{s}, \mathrm{z}, 3, \mathrm{~h} /$, one lateral / $1 /$, three nasals / $\mathrm{m}, \mathrm{n}, \mathrm{y} /$ and three glides $/ \mathrm{r}, \mathrm{w}, \mathrm{j} /$. According to POA, English has four bilabials / b , p , m , w /, two labio- dentals / f , v / , two interdentals / $\theta$, $\mathrm{\partial} /$, seven alveolars / t , d , s , z , l, r , n / , four palato-alveolars $/ \int, \mathrm{t} \int, \mathrm{d} 3, \mathrm{3} /$, one palatal $/ \mathrm{j} /$, three velars $/ \mathrm{k}, \mathrm{g}, \mathrm{y} /$ and one glottal $/ \mathrm{h} /$, ( Catford ,J .1988 ).

\section{Findings, Recommendations and Conclusion}

\subsection{Results Related to the First Question of the Study}

What are the speech sounds in the Arabic language that don't have counterparts in the English language and vice versa? Arabic is the official language in many countries, including Jordan, Syria, Egypt, Iraq, Saudi Arabia, and Morocco. Arabic is also the language of the Koran, so Muslims of all nationalities, such as Indonesians, are familiar with it. However, the phonological system of modern standard Arabic is made up of 28 consonants and 6 pure vowels. Fifteen of the consonants in addition to two diphthongs are very much like English sounds and raise no difficulties. The reaming ones differ from English consonants in one way or another in their articulations to different extents, (AL-Ani1970:29).

The results showed that there are Arabic speech sounds that have counterparts in English speech sounds such as / $\mathrm{b}, \mathrm{f}, \mathrm{k}, \mathrm{l}, \mathrm{m} \ldots /$.

Thus, these similarities between the speech sounds of the two languages facilitate and have positive effects on the process of learning English language. On the other hand, the results also showed that there are speech sounds in the Arabic language that don't have counterparts in the English language such as (glottal stops) : 
غ/, / y / [fa:re y] "empty"

/,/ d / / [d [

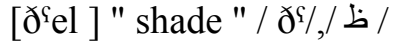

[s'a:m] " fast " / s//ص/

[Qæl] " he said"/Q , /

In contrast, there are speech sounds in the English language that are not found in the Arabic language

like:

/p / ( pen /pen/, people / pi:pl / )

$/ \mathrm{y} /($ writing $/ \mathrm{raity} /,(\operatorname{sing} / \mathrm{sin} /) /$

/3/ ( pleasure / pləzə / ), (erosion / Iro:3n/ )

/v/ ( van / væn/, leave / li:v/

Therefore, due to these differences in the speech sounds of both languages, they have negative effects on the process of learning English language and so learners face difficulty in pronouncing these sounds correctly. Moreover, Arab EFL learners have problems in pronouncing consonants include the inability to produce the sounds in words, such as $/ \delta /$ this and $/ \theta /$ thin, the swapping of $/ \mathrm{b} /$ and $/ \mathrm{p} /$ at the beginning of words, and the substitution of /f/ for / $/$ /.

\section{3 .2 Results Related to the Second Question of the Study}

How does the mother tongue( Arabic Language ) interfere in pronouncing some sounds in English?

Mother-tongue is the first language acquired by a child and it is successfully used for communication at that level. One characteristic of language is finding names for objects and persons within the child's reach, so it is possible for a child to grasp, repeat and understand the word. Though, bilingualism assists the child's general intellectual and conceptual development as well, (Amuseghan, 2007). However, Krashen (1981) stated that many skills acquired in the first language can be transferred to the second language. Errors in foreign/second language learning are partly attributable to interference. Interference as a linguistic problem is common in communities where foreign/second languages must be learned. In other words, interference is a term which refers to a situation whereby two different languages overlap. Interference is either positive or negative transfer of the linguistic knowledge of a language into performance in the other. Negative transfer pertains to difficulties in using the target language which is mainly attributed to mother -tongue interference. Positive transfer, however, implies the ease or facilitation in learning the L 2 resulting from similarities between the L 1 and L 2. Two types of interference can be distinguished.

Accordingly, mother tongue interference and overgeneralization rules affect the pronunciation and spelling of some English words. It is clear that the interference of the Arabic language in pronouncing English consonants include the inability to produce the sounds in words, such as the swapping of $/ \mathrm{b} /$ and $/ \mathrm{p} /$ at the beginning of words because the phoneme /p/does not exist on Arabic language while there is only phoneme /b/ for this reason; most Arabic speakers mispronounce words with these distinctive sounds $/ \mathrm{p} /$ and $/ \mathrm{b} /$. The main reason for shifting $/ \mathrm{p} /$ to $/ \mathrm{b} /$ is the fact that the two sounds are regarded as two allophones of one phoneme. Moreover, the substitution of /f/ for / v/ because the phoneme /v/ does not exist in the Arabic language as well as the absence of the phoneme $/ \mathrm{y} /$, in the Arabic language causes difficulty in pronouncing some English words. Consequently, the absence of these speech sounds in the Arabic language is considered as a negative transfer that causes difficulties in using the target language which is mainly relevant to mother -tongue interference. Thus, consonant clusters, such as in the words split, threw, next or lengths, also cause problems and often result in the speaker adding an extra vowel: * spilit, thirew, nexit or lengiths.*

This research also revealed that Arab EFL learners encounter many problems in learning English pronunciation especially with unfamiliar sounds that do not exist in their mother tongue. This could be due to the lack of some speech sounds in their mother tongue. Though, the researcher suggested some procedures to decrease mother tongue interference:

1 - Teachers encourage using media such as listening to English songs, watching English news and movies that may affect their pronunciation competence.

2 - Teachers introduce more authentic texts, message-oriented communication that might be found in lessons where they are avoided.

3 - Students ought to have more and more ear-training to listen to native speakers.

4 - They also should trained on pronouncing the vowels ( a: :a ) (e / i: )....etc. 
5 - Practical training on reading different texts aloud.

6 - Chorally repetition is recommended.

Consequently, it is not possible to avoid interference, but it can be greatly reduced. Still, the role of teachers has been served up trivial and banal arguments that nobody would deny: "One cannot learn a foreign language if one constantly speaks another language"; likewise: "the mother tongue causes interference errors at all levels of language. However, the perception that the mother tongue apparently traps and tricks the learners into making mistakes, prevents them from realizing a deeper truth: interference is nothing other than knowledge or skills that learners do not yet possess. What can the learner do other than use what he already knows to make up for what he does not know? "The problem of 'interference' viewed, thus, reduces to the problem of ignorance." (Newmark \& Reibel, 1968: 160).

\section{3 Results Related to the Third Question of the Study}

-What are the practical procedures to improve English language pronunciation of Arab EFL learners?

If the learners do not have a native English speaker to monitor them, simply listen and repeat with the Elemental English pronunciation, speaking lessons, and take note of how your pronunciation differs from theirs. For example, does $/ \theta /$ as in "think" / $\theta \mathrm{Ink} /$ sound like $/ \mathrm{t} / \mathrm{or} / \mathrm{s} /$, as in "tink" or "sink", when they say it? Once the learners become aware of the errors they make, they are then ready to correct them. Here are some useful and practical procedures that could improve English language pronunciation of Arab EFL learners:

\subsubsection{Teacher's role:}

Teachers as models of pronunciation carry a huge responsibility for their classrooms. They influence their learners either in a positive or negative way and their main goal is to create a friendly and supportive atmosphere. On one hand, their practical proficiency is insufficient if the teacher can only exemplify pronunciation by his or her own speech performance; the learners are left to work out what is significant for them. Learners of a second language will not readily discern crucial phonological distinctions (Dalton and Seidlhofer 1994: 67). On one hand, there are so-called gifted learners that are able to pick up the pronunciation of the target language only by being exposed to it .On the contrary, many students, if not majority, need as explicit explanations as possible to be able to acquire and imitate difficult sounds when speaking.

- Teaching the phonemes one by one:

This was divided into four parts:

- Vowel and Diphthong sounds: east bank near where

- Consonant sounds: here hat play tree

- Stress patterns: infect |infect |

- Intonation patterns: yes? Shows surprise.

- Teaching pronunciation according to three main sections:

- Individual sounds. It covers: 'stress', some sounds in words and some words in sentences are clearer than others.

- 'Intonation', the rise and fall of the voice; e.g. to show statement, question or surprise.

- 'Steps for Studying Pronunciation'. The teacher can do this in two ways

- Helping learners hear

The role of teachers is to help their students to perceive sounds that are often misperceived because of the false similarity in learners' mother tongue. Teachers need to check whether their learners are hearing sounds according to the appropriate categories and help them to develop new categories if necessary (Kenworthy 1990: 1)

\section{- Helping Learners Make Sounds}

In this situation, teachers have to explain and guide their students how to imitate and pronounce new sounds that do not exist in their mother tongue.

\subsubsection{Providing Feedback}

Teachers need to give their students accurate and constructive feedback about how they are doing since they are not able to judge whether their pronunciation is comprehensible or not. However, providing students with feedback could mean that students make wrong assumptions about pronunciation. 


\subsubsection{Establishing Priorities}

Learners themselves are aware that their pronunciation is in some ways different in comparison with native speakers, but what they are unaware of is whether it is relevant or not. Here, teachers guide them which features they should focus on and which not.

\subsubsection{Assessing Progress}

Assessing progress is not an easy task for any teacher but providing students with information about their progress is essential for further motivation. In conclusion, during the pronunciation teaching teachers not only serve as guides, who help their students to form necessary categories, establish priorities but also they need to provide their students with appropriate exercises and relevant feedback.

\subsubsection{Encourage learners to speak and 'show off' and build self- confidence.}

In the first class the teacher wrote a big word, 'confidence' on the board and told the learners whatever they did, this was very important. Teachers should encourage and grasp every chance to encourage their students and praise them on every step of progress they make, either a correct pronunciation or a volunteering answer.

\section{Recommendations}

Based on the results of the research, some suggestions and strategies are given below which may help students and teachers in reducing difficulties in pronunciation:

- The researcher believed that further study is needed to determine the effects of speech sounds of the Arabic language and their effect on learning English as a foreign language

- Students should be taught phonetics and phonology in their earlier stage of studying English.

- Students should be provided with more pronunciation practices to improve their pronunciation performances.

- Special attention should be paid to the unfamiliar sounds (which do not exist in the learners' mother tongue).

- Students should be asked to read aloud the text with the teacher's support. If the student commits any mistakes while reading aloud, the teacher should correct.

- Students should be given enough instructions or opportunities to learn pronunciation within the English language courses.

- Students should be encouraged to watch some English programs on TV or other visual media, such as BBC English, CNN, etc.

- Students should use the pronunciation learning strategies (PLS) to help them improve their pronunciation.

\section{Conclusion}

To sum up, the results showed that there are speech sounds in the Arabic language that have counterparts in the English language such as / b , f , k , 1, m .../. Thus, these similarities between the speech sounds of the two languages facilitate the process of learning English language and have positive effects on it. Furthermore , this research also revealed that Arab EFL learners encounter many problems in learning English pronunciation especially with unfamiliar speech sounds that do not exist in their mother tongue since there are speech sounds in the Arabic language that do not have counterparts in English language such as the (glottal stops) : / $/ \mathrm{L} / \mathrm{y} /$

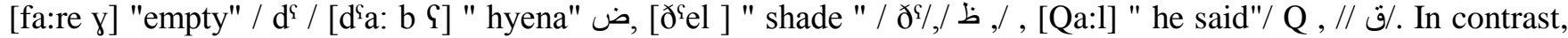
there are speech sounds in English are not found in the Arabic language like/ p / ( pen /pen/ ), / y/ ( writing / raity/ , /3/ ( pleasure / plozə / ) , /v/ ( van / væn/ ). Therefore, due to these differences in the speech sounds of both languages, they have negative effects on the process of learning the English language and learners face difficulty in pronouncing these sounds correctly. Accordingly, mother tongue interference and overgeneralization rules affect the pronunciation and spelling of some English words. The findings of this study pointed out the importance of teaching pronunciation in schools and increased the teachers' awareness of the English phonetic system. Since teachers are the first source of input for the students, they must have strong phonetics and phonology base as the students can acquire proper pronunciation from them. 


\section{References}

Al-Ani, S.H.(1970). Arabic Phonology . An Acoustical and Phonological Investigation . Paris: Muton

Alshangiti ,W. (2015) . Speech production and perception in adult Arabic learners of English: A comparative study of the role of production and perception training in the acquisition of British English vowels. (Unpublished PhD Dissertation), University College London (UCL).

Amayreh, M. (2003). Completion of the Consonant Inventory of Arabic. Journal of Speech, Language, and Hearing Research,41,642ň653.

Avery, P. and Ehrlich, S. (1992).Teaching American English pronunciation. Oxford, England: Oxford University Press

Barros, A. M. (2003). Pronunciation difficulties in the consonant system experienced by Arabic speakers when learning English after the age of puberty,(Unpublished Master Dissertation) West Virginia University, Morgantown: USA.

Catford ,J .(1988 ). A Practical Introduction to Phonetics . Oxford, Oxford University Press.

Crystal, D. (1983)"A first Dictionary of linguistics and phonetics "Andre Deutch LTD., London.

Dalton, Christian and Seidlhofer, Barbara (1994). Pronunciation. Oxford: Oxford University Press

Ha, N. N. (2013). Using Language Learning Strategies in Pronunciation Training for Non-English Major Students (Doctoral dissertation).

Gilakjani, A. (2012 ). English Pronunciation Instruction: A Literature Review. IJREE. Vol.1,No1;2016.

Johansson, S. (2008). A Contrastive Analysis and Learner Language: A Corpus-Based Approach. University of Oslo. Online book.

Katamba, Francis (1989): An Introduction to Phonology .London: Longman.

Kenworthy, J. (1990). Teaching English Pronunciation. Longman, Harlow.

Kharma, N., \& Hajjaj, A. (1989). Errors of English among Arabic speakers. Alfred Place, London.

Khattab, G., Al-Tamimi, F., and Heselwood, B. (2006). Acoustic and auditory differences in the /t/- /T/ opposition in male and female speakers of Jordanian Arabic. In S. Boudelaa (Ed.), Perspectives on Arabic Linguistics XVI: Papers from the sixteenth annual symposium on Arabic linguistics, pp. 131-160. Cambridge, UK: John Benjamins.

Krashen, D.(1981) "Second language Acquisition and second language-learning .Pergamon press Ltd, Oxford, England.

Ladefodged, P. (1982)" A course in phonetics" Harcourt Brace Jovanovich Inc.

Lado, R. (1957). Linguistic Across Cultures. Ann Arbor: University of Michigan Press.

Marcel, L (2012) . Problems Arabic Students Have in English. CATESOL Regional Conference. http://eslatpalomar.blogspot.com/2012/11.

Munro, J. and Derwing, T. (2011). The foundations of accent and intelligibility in pronunciation research. Language Teaching, 44(3), 316-327.

Newmark, L. and Reibel, D. A. (1968). Necessity and sufficiency in language learning. IRAL, 6, 3, 14564.CrossRef

O’Connor, J.P. (1967) " Better English Pronunciation "C.V.P. Cambridge.

Oxford, R. (1990). Language learning strategies: What every teacher should know. New York: Newbury House. Pourhosein Gilakjani, A. (2016). What Factors Influence English Pronunciation of EFL Learners? Modern Journal of Language Teaching Methods (MJLTM), 6(2), 314-32.

Qaid, Y. A., and Ramamoorthy, L. (2011). A study of Arabic interference in Yemeni university students' English writing. Language in India, 11(4), 28-37.

Spencer, A. (1996). Phonology: Theory and Description, 9. Oxford: Wiley-Blackwell.

Spencer, L.J., Tye -Murray, N., and Tomblin, J.B. (1998). The production of English inflectional morphology, speech production and listening performance in children with cochlear implants. Ear and Hearing, 19, 310-318.

Thelwall, Robin (1990), "Illustrations of the IPA: Arabic", Journal of the International Phonetic Association, 20 (2): 37-41,doi:10.1017/S0025100300004266

Yates, L., and Zielinski, B. (2009). Give It a Go: Teaching Pronunciation to Adults. Sydney, Australia: AMEPRC. Available: http://www.ameprc.mq.edu.au/resources/classroom_resources/give_it_a_go. 


\section{Appendix ( 1 )}

For comparison purposes, the consonant inventories of Arabic and English are both outlined. There are 28 consonant phonemes as shown in Table 1, adopted from Al-Ani (1970) and Ingham (1971) The phonemic inventory of Arabic consonants is represented by a wide range of sounds, among which are the universally less frequent uvular, pharyngeal and glottal places of articulation. with modification. The table below shows the phonetic symbols used in transcribing Arabic phonemes. It includes the corresponding Arabic letters and IPA symbols to make comparisons easier for the reader.

\section{The phonemic inventory of Arabic consonants}

\begin{tabular}{|c|c|c|}
\hline Arabic Letter & IPA Symbol & Sound Description \\
\hline i & $?$ & Voiced glottal plosive \\
\hline ب & $\mathbf{B}$ & Voiced bilabial plosive \\
\hline$ت$ & $\mathbf{T}$ & Voiceless dento-alveolar plosive \\
\hline$\dot{\leftrightarrow}$ & $\boldsymbol{\Theta}$ & Voiceless interdental fricative \\
\hline ج & d3 & Voiced post alveolar fricative \\
\hline$\tau$ & $\mathrm{H}$ & Voiceless pharyngeal fricative \\
\hline$\dot{\tau}$ & $\mathbf{X}$ & Voiceless velar fricative \\
\hline 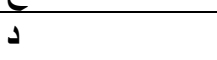 & $\mathrm{D}$ & Voiced dento-alveolar plosive \\
\hline$\dot{j}$ & † & Voiced interdental fricative \\
\hline J & $\mathbf{R}$ & $\begin{array}{l}\text { Voiced alveolar glide or } \\
\text { Voiced velarized glide }\end{array}$ \\
\hline j & $\mathbf{Z}$ & Voiced alveolar fricative \\
\hline س & $\mathbf{S}$ & Voiced alveolar trill \\
\hline ش & $\int$ & Voiceless alveo-palatal fricative \\
\hline ص & $\mathbf{s}_{\mathbf{S}}$ & Voiceless velarised/emphatic alveolar fricative \\
\hline ض & $d^{\mathrm{s}}$ & Voiced velarised/emphatic dento-alveolar plosive \\
\hline b & $\mathbf{t}^{\mathrm{s}}$ & Voiceless velarised/emphatic dento-alveolar plosive \\
\hline ظ & $\dot{\partial}^{\mathrm{s}}$ & Voiced velarised/emphatic interdental fricative \\
\hline$\varepsilon$ & S & Voiced pharyngeal fricative \\
\hline$\dot{\varepsilon}$ & $\mathrm{Y}$ & Voiced velar fricative \\
\hline ف & $\mathbf{F}$ & Voiceless labio-dental fricative \\
\hline ق & $\mathbf{Q}$ & Voiceless uvular plosive \\
\hline ك) & $\mathbf{K}$ & Voiceless velar plosive \\
\hline J & $\mathbf{L}$ & Voiced dental lateral \\
\hline b & $\mathbf{M}$ & Voiced bilabial nasal \\
\hline ن & $\mathbf{N}$ & Voiced alveolar nasal \\
\hline هـ & $\mathbf{H}$ & Voiceless glottal fricative \\
\hline 9 & $\mathbf{W}$ & Voiced labio-velar glide \\
\hline ي & $\mathbf{J}$ & Voiced palatal glide \\
\hline
\end{tabular}

Adopted from Al-Ani (1970) with modifications 